\title{
PERBEDAAN ANTARA EKSPRESI CD3, CD20, CD43 LIMFOMA NON-HODGKIN SEL B DAN LESI LIMFOPROLIFERATIF REAKTIF
}

\author{
Muhammad Luqman Fadli*® ${ }^{\star 凶}$ Eviana Norahmawati ${ }^{\star}$, Hendy Setyo Yudhanto*, Harun Al Rasyid ${ }^{\star \star}$
}

Abstrak

Lesi limfoproliferatif sering menimbulkan masalah dalam penegakan diagnosis karena kemiripan morfologi dan pola pertumbuhan sel-sel limfoid yang menyusun lesi limfoproliferatif reaktif dan limfoma nonHodgkin Sel B. Diagnosis sulit ditegakkan hanya dengan pulasan rutin Hematoksilin-Eosin, oleh karena itu diperlukan pemeriksaan imunohistokimia menggunakan panel antibodi yang tepat. Penelitian ini bertujuan untuk mengetahui perbedaan ekspresi CD3, CD20, CD43 sebagai panel antibodi dasar dalam menentukan karakter jinak atau ganas dari lesi limfoproliferatif. Karakter jinak diwakili oleh lesi limfoproliferatif reaktif, sedangkan karakter ganas diwakili oleh limfoma non-Hodgkin sel B. Total 50 sampel dibagi menjadi 2 kelompok, yakni kelompok A terdiri dari 25 sampel limfoma non-Hodgkin sel B dan kelompok B terdiri dari 25 sampel lesi limfoproliferatif reaktif. Keseluruhan sampel dipulas antibodi CD3, CD20, CD43. Hasil penelitian menunjukkan persentase imunopositif $\mathrm{CD} 3$ dan $\mathrm{CD} 20$ pada kelompok $A$ dan $\mathrm{B}$ berbeda signifikan dengan nilai $p<0,001$. Hal ini menunjukkan bahwa CD3 dan CD20 mampu membedakan karakter klonalitas jinak dan ganas dari sel penyusun lesi limfoproliferatif. Persentase imunopositif CD43 antara kelompok A dan B tidak berbeda signifikan dengan nilai $p=0,791$. Hasil yang tidak berbeda signifikan mengindikasikan bahwa CD43 diekspresikan oleh dua jenis populasi sel yang berbeda. Pada kelompok $A, C D 43$ diekspresikan oleh limfosit B neoplastik (ganas), sedangkan pada kelompok B diekspresikan oleh limfosit T. Berdasarkan hasil penelitian, panel antibodi CD3, CD20, CD43 dapat membedakan lesi limfoproliferatif jinak dan ganas, namun diperlukan korelasi morfologi dan kesesuaian pola ekspresi imunopositif dari sel-sel limfoid penyusunnya.

Kata kunci: CD3, CD20, CD43, Lesi limfoproliferatif reaktif, Limfoma non-Hodgkin sel B.

\section{THE EXPRESSIONS DIFFERENCES OF CD3, CD20, CD43 NON-HODGKIN LYMPHOMA B CELL TYPE AND REACTIVE LYMPHOPROLIFERATIVE LESION}

\begin{abstract}
Lymphoproliferative lesion often induces a diagnosis problem due to lymphoid cell morphology and growth pattern similarities between reactive lymphoproliferative lesion and non-Hodgkin lymphoma B cell types. The diagnosis establishment is difficult using only Hematoxylin-Eosin. Immunohistochemistry is required to make a precise diagnosis. The objective of this study is to identify the differences between CD3, CD20, CD43 expressions for determining benign and malignant characteristics of lymphoproliferative lesion. Benign lesion represented by reactive lymphoproliferative lesion, whilst malignant lesion represented by non -Hodgkin lymphoma B cell type. Fifty samples divided into two groups composing 25 samples of nonHodgkin lymphoma B cell type in group A and 25 samples consisting of reactive lymphoproliferative lesion in group $B$. All samples were immunostained with $C D 3, C D 20, C D 43$. The results showed $C D 3$ and $C D 20$ positive area significantly different between group $A$ and $B$ with $p<0.001$. These results showed $C D 3$ and $\mathrm{CD} 20$ able to differentiate benign and malignant clonalities of lymphoproliferative lesion. CD43 positive area was not significantly different between groups $A$ and $B$ with $p=0.791$. The insignificant result of $\operatorname{CD} 43$ probably due to CD43 is expressed by different cells population. CD43 was expressed by neoplastic (malignant) $B$ lymphocytes in group $A$, but $C D 43$ was expressed by $T$ lymphocytes in group $B$. According to the results, antibodies panel of $\mathrm{CD} 3, \mathrm{CD} 20, \mathrm{CD} 43$ can differentiate benign and malignant characteristics of the lymphoproliferative lesion. However, it requires a correlation of lymphoid cell morphology and immunostaining pattern.
\end{abstract}

Keywords: CD3, CD20, CD43, non-Hodgkin lymphoma B cell type, reactive lymphoproliferative lesion.

* Program Studi Spesialis Patologi Anatomi, Fakultas Kedokteran, Universitas Brawijaya-RSUD dr. Saiful Anwar Malang

** Departemen IImu Kesehatan Masyarakat dan Kedokteran Pencegahan, Fakultas Kedokteran, Universitas Brawijaya

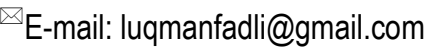




\section{Pendahuluan}

Lesi limfoproliferatif seringkali menimbulkan masalah dalam penegakan diagnosis. Masalah timbul karena lesi limfoproliferatif jinak dan ganas sulit untuk dibedakan. ${ }^{1,2}$ Kesulitan dalam menentukan suatu lesi limfoproliferatif bersifat jinak atau ganas dikarenakan aspek klinikopatologi yang mirip di antara keduanya. Sel-sel limfoid antara lesi limfoproliferatif jinak dan ganas memiliki morfologi dan pola pertumbuhan sel yang mirip. ${ }^{3}$

Lesi limfoproliferatif ganas disebut limfoma. Jenis limfoma terbanyak ialah limfoma non-Hodgkin dan $90 \%$ di antaranya merupakan jenis sel B. ${ }^{4}$ Sedangkan lesi limfoproliferatif jinak disebut reaktif. Berbagai jenis limfadenitis dengan etiologi spesifik maupun non -spesifik termasuk dalam lesi limfoproliferatif reaktif. 5,6

Kasus baru limfoma kurang lebih sebanyak 566.000 dengan jumlah kematian sekitar 305.000 kasus pada tahun 2012. Dapat dikatakan bahwa penambahan jumlah kasus limfoma diikuti oleh penambahan angka kematian yang tinggi. ${ }^{4}$

Tipe klonalitas dari sel limfoid yang mengalami proliferasi merupakan faktor yang dapat membedakan sifat jinak atau ganas pada lesi limfoproliferatif. Proliferasi monoklonal cenderung suatu ciri limfoma, sedangkan poliklonal merupakan ciri lesi reaktif atau jinak. 7,8

Imunohistokimia merupakan bagian integral dari diagnosis limfoma non-Hodgkin sel B dan subtipenya. 2,9,10 Imunohistokimia dapat menentukan galur diferensiasi sel limfoid, mengidentifikasi maturasi dan fungsi sel limfoid, mengetahui tipe klonalitas, serta respons terhadap kemoterapi. ${ }^{10,11,12}$

Penelitian ini bertujuan untuk mengetahui apakah terdapat perbedaan ekspresi
CD3, CD20, CD43 di antara lesi limfoproliferatif jinak dan ganas.

\section{Bahan dan Metode}

\section{Sampel Penelitian}

Penelitian dilakukan di Laboratorium Patologi Anatomi Fakultas Kedokteran, Universitas Brawijaya dengan sampel blok parafin dari Instalasi Patologi Anatomi RS. Dr. Saiful Anwar Malang tahun 2017-2018. Total 50 sampel dibagi menjadi kelompok $A$ dan $B$ masing-masing sebanyak 25 sampel. Kelompok $A$ terdiri dari limfoma non-Hodgkin sel $B$ yang telah dilakukan pulasan imunohistokimia CD3 dan CD20. Kelompok B terdiri dari limfadenitis yang disebabkan proses spesifik maupun nonspesifik, hiperplasia limfoid, lesi kelenjar getah bening tanpa keganasan. Penelitian ini telah mendapat persetujuan laik etik dari Komisi Etik Penelitian Kesehatan RS. Dr. Saifu; Anwar malang dengan nomor surat: 400/056/K.3/302/2019.

Pemulasan CD3, CD20, dan CD43 dengan Teknik Imunohistokimia

Teknik imunohistokimia menggunakan metode polymer dari jaringan terfiksasi formalin dalam blok parafin. Langkah awal ialah pemotongan blok parafin menggunakan mikrotom, deparafinisasi, antigen retrieval dalam decloacking chamber dengan suhu 95 ${ }^{\circ} \mathrm{C}$ dan $\mathrm{pH}$ 9. Antibodi primer menggunakan CD3 (Cell Marque RU010339020), CD20 (Cell Marque RU012028040), CD43 (Biocare CM005C). Antibodi sekunder menggunakan Universal Immunoperoxidase Polymer (Histofine, H1810, Nichirei) dengan kromogen diaminobenzidine (DAB 2V; Histofine, H1806, Nichirei). Counter stain menggunakan hematoksilin. Proses pemulasan dilakukan secara manual sesuai standar prosedur operasional. Semua sampel dipulas imunohistokimia CD3, CD20, dan CD43. 


\section{Analisis Ekspresi CD3, CD20, dan CD43}

Luas area imunopositif (ekspresi positif dari CD3, CD20, CD43) dihitung dalam satuan persentase menggunakan grid (garis imajiner komputer) pada gambar pindaian dot -slide scanner. Persentase luas area imunopositif dirata-rata dari 5 lapang pandang terpilih berdasarkan penilaian imunoarsitektur (pola ekspresi antigen imunohistokimia) menggunakan pembesaran 100x mikroskop binokular Olympus BX43. Analisis data dilakukan dengan uji $t$ independen menggunakan SPSS versi 23.0 untuk mengetahui perbedaan luas area positif dari ekspresi CD3, CD20 CD43.

\section{Hasil}

Semua sampel dihitung luas area imunopositif CD3, CD20, CD43 dengan didahului penilaian imunoarsitektur untuk mendapatkan area representatif. Ekspresi dianggap positif jika terdapat deposit warna coklat pada membran sel limfoid.

Penghitungan ekspresi CD3, CD20, CD43 dikatakan terdapat perbedaan bermakna jika $p<0,05$. Berdasarkan hasil analisis statistik uji t independen, ekspresi CD3 dan CD20 menunjukkan adanya perbedaan signifikan antara kelompok $A$ dan $B(p<0,001)$. Sementara ekspresi CD43 tidak menunjukkan adanya perbedaan signifikan $(p=0,791)$.

Ekspresi CD3, CD20, CD43 pada Tiap Kelompok

Penilaian imunoarsitektur kelompok A menunjukkan ekspresi CD3 cenderung negatif atau dalam sebaran minimal tanpa pola tertentu. Ekspresi CD20 tampak positif difus, sedangkan ekspresi CD43 cenderung memiliki pola sebaran difus yang mirip dengan ekspresi CD20, namun dengan intensitas lebih lemah.

Penilaian imunoarsitektur kelompok $B$ menunjukkan ekspresi CD3 terletak pada parakorteks. Mayoritas ekspresi CD20 positif terletak pada folikel atau germinal center di zona korteks, sedangkan ekspresi CD43 positif terletak pada parakorteks yang mirip dengan ekspresi CD3. Perbandingan ekspresi positif CD3, CD20, dan CD43 ditampilkan pada Gambar 1. Sementara, ekspresi CD3, CD20, CD43 positif dalam pembesaran 100x ditampilkan pada Gambar 2.

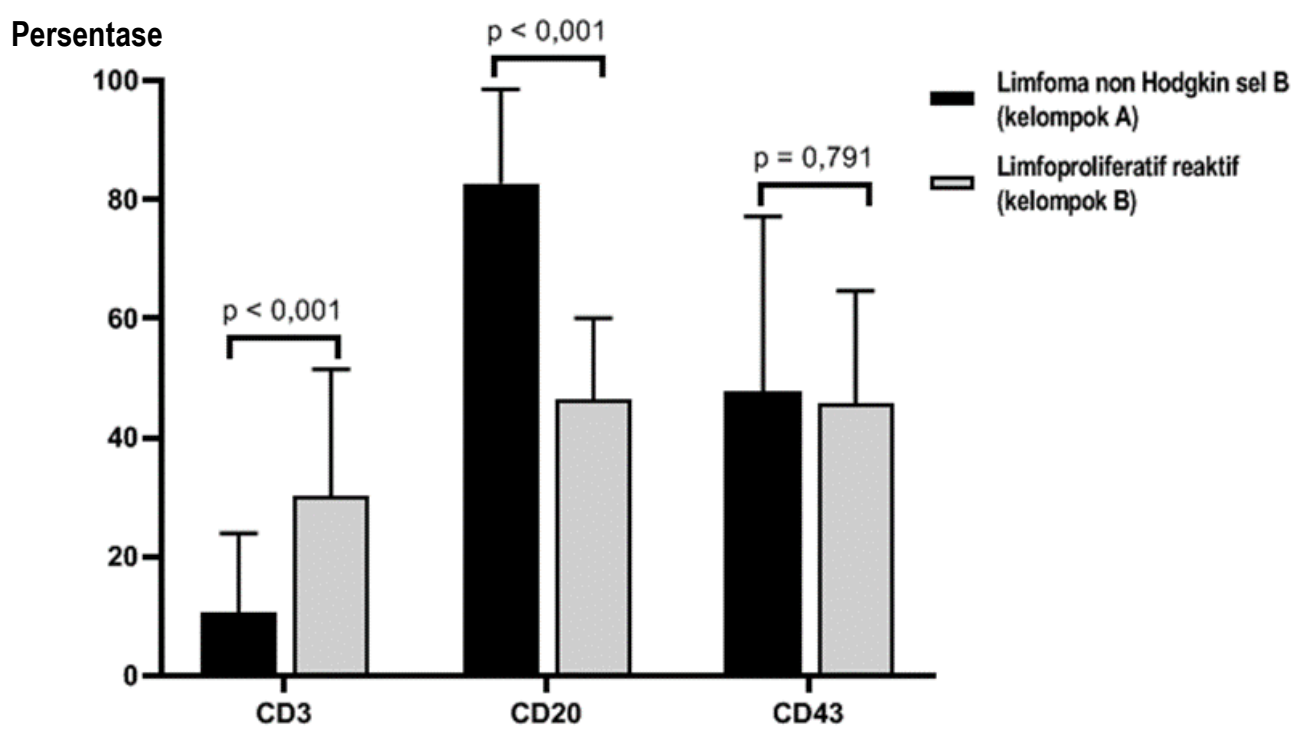

Gambar 1. Rerata ekspresi positif CD3, CD20, CD43 pada kelompok A (limfoma non-Hodgkin sel B) dan B (limfoproliferatif reaktif). 

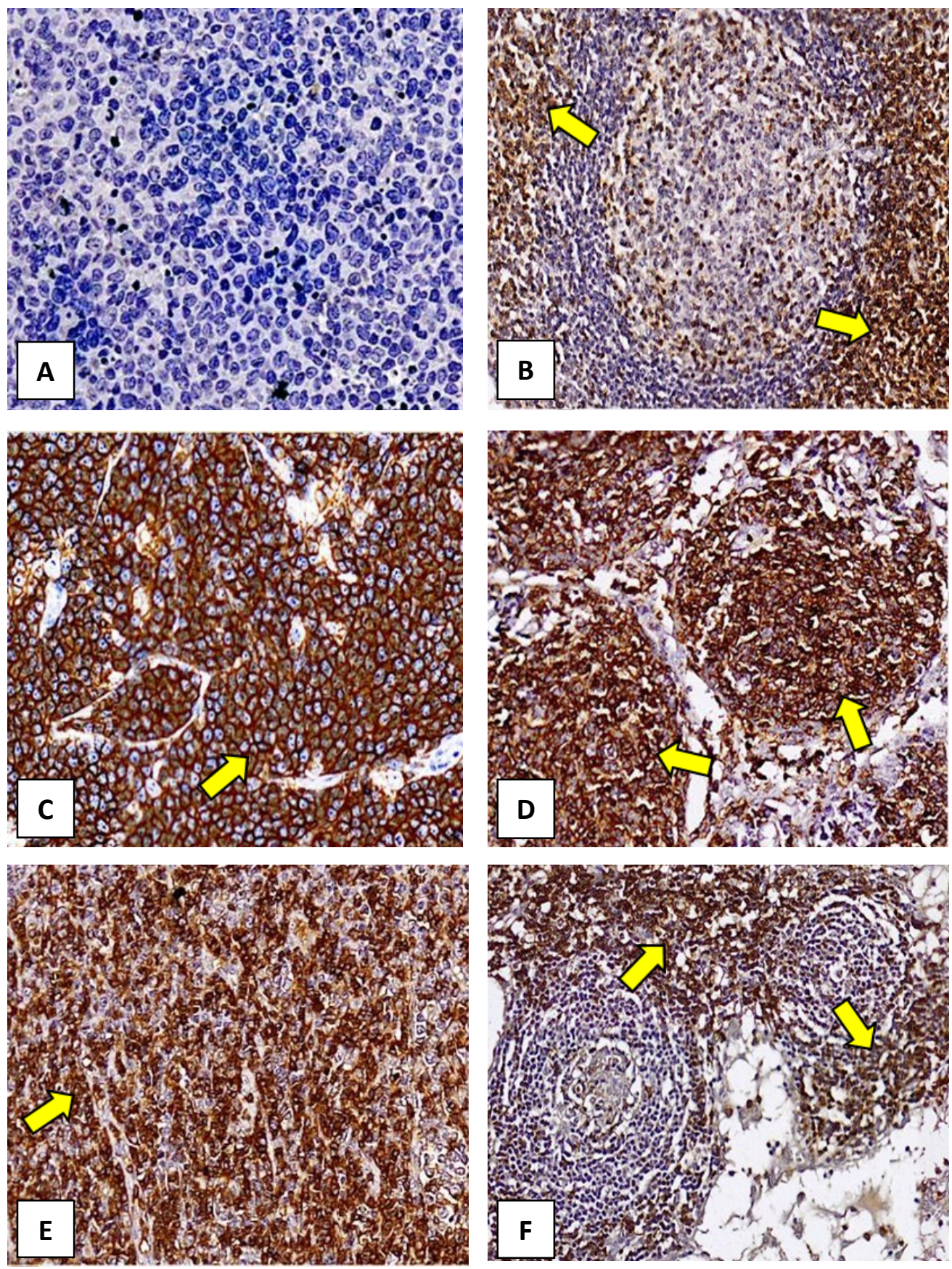

Gambar 2. Ekspresi CD3, CD20, CD43 positif pada kelompok A (limfoma non-Hodgkin sel B) dan $B$ (limfoproliferatif reaktif) (100x).

Keterangan: A. Ekspresi CD3 kelompok A tampak negatif; B. Ekspresi CD3 kelompok B tampak positif pada parakorteks (tanda panah kuning); C. Ekspresi CD20 kelompok A tampak positif difus (tanda panah kuning; D. Ekspresi CD20 kelompok B tampak positif intrafolikel (tanda panah kuning; E. Ekspresi CD43 kelompok A tampak positif difus (tanda panah kuning; F. Ekspresi CD43 kelompok B positif pada parakorteks (tanda panah kuning). 


\section{Pembahasan}

Diagnosis lesi limfoproliferatif sering menimbulkan kesulitan dalam praktek ahli patologi oleh karena kemiripan morfologi dan pola pertumbuhan sel-sel penyusunnya. ${ }^{3}$ Identifikasi karakteristik lesi jinak atau ganas mutlak diperlukan untuk penegakan diagnosis. Penentuan sifat jinak dan ganas dilakukan dengan menilai klonalitas sel penyusun lesi limfoproliferatif menggunakan pemeriksaan imunohistokimia. Lesi jinak memiliki ciri poliklonal dan disebut reaktif, sedangkan lesi ganas memiliki ciri monoklonal dan disebut limfoma. ${ }^{13}$

Imunohistokimia merupakan bagian integral dari penegakan diagnosis dan klasifikasi limfoma. 2,9,10,13 Imunohistokimia memiliki keunggulan karena dapat menilai morfologi, lokasi-distribusi sel, serta ekspresi antigen secara simultan. Selain itu, juga dapat menentukan tingkat keparahan (grading) dan mengevaluasi respons kemoterapi.2,14,15 Imunohistokimia secara teknis dapat di-lakukan pada laboratorium diagnostik patologi secara luas dan efisien karena menggunakan blok parafin dari pemeriksaan histopatologi sebelumnya, sehingga tidak membutuhkan pengambilan jaringan ber-ulang. ${ }^{10,11,12}$

Imunohistokimia pada penelitian ini dilakukan menggunakan panel antibodi CD3, CD20, CD43. Ketiga antibodi ini dipilih untuk membedakan karakter jinak atau ganas dari lesi limfoproliferatif reaktif dan limfoma nonHodgkin sel B. CD3 merupakan penanda sel limfosit $T$ yang memiliki sensitivitas dan spesifitas baik. CD3 diekspresikan oleh $80 \%$ limfoma non-Hodgkin sel $\mathrm{T}$ dan tidak terdapat jenis limfoma non-Hodgkin sel B yang mengekspresikannya. Selain itu, CD3 dapat diandalkan untuk mengevaluasi jaringan dengan nekrosis luas. Hal ini menjadikan CD3 unggul di antara antibodi-antibodi yang mendeteksi limfosit T lainnya. ${ }^{2,10}$

CD20 merupakan antibodi penanda limfosit $B$ dengan spektrum lebar dan umum digunakan. CD20 diekspresikan oleh 90\% limfoma non-Hodgkin sel B dan sangat jarang diekspresikan oleh limfoma non-Hodgkin sel T.10 Selain itu, CD20 dapat menentukan kemoterapi target rituximab (anti-CD20) dapat diberikan atau tidak pada penderita. ${ }^{14,15}$

CD43 atau leukosialin merupakan protein terglikosilasi yang spesifik pada permukaan sel limfosit T.16,17 Ekspresi CD43 dapat mengonfirmasi apakah sel-sel limfoid proliferatif yang mengekspresikan CD3 maupun CD20 merupakan sel jinak atau ganas. Hal ini karena CD43 berfungsi sebagai penanda limfosit $T$ dan makrofag pada jaringan KGB normal maupun lesi reaktif, namun menjadi penanda limfosit B neoplastik atau ganas pada limfoma non-Hodgkin sel B. 10,18,19,20,21

Hasil penelitian menunjukkan rerata luas area CD3 positif pada kelompok A 10,61\% $(10,6132 \pm 13,268)$ dan kelompok B 30,17\% $(30,1664 \pm 21,315)$. Perbandingan rerata luas area CD3 positif antara kelompok $A$ dan $B$ menunjukkan perbedaan signifikan dengan nilai $p<0,001$. Secara statistik CD3 mampu membedakan karakter populasi limfosit $\mathrm{T}$ pada kelompok $A$ dan B. Penilaian imunoarsitektur menunjukkan ekspresi CD3 kelompok A cenderung negatif atau dalam sebaran minimal tanpa pola tertentu, sedangkan ekspresi CD3 positif kelompok B terletak di parakorteks.

Pola imunoarsitektur ekspresi CD3 pada kelompok $A$ dan $B$ berbeda. Ekspresi CD3 negatif kelompok $A$ menunjukan tidak adanya populasi limfosit $T$ oleh karena adanya proliferasi sel limfosit $B$ neoplastik yang mendesak populasi limfosit T. Hal ini sesuai dengan profil sel-sel penyusun limfoma non-Hodgkin sel B. Ekspresi CD3 positif kelompok $B$ yang terletak di parakorteks merupakan gambaran distribusi limfosit $T$ yang sesuai pada kelenjar getah bening normal, jaringan limfoid reaktif maupun hiperplasia. ${ }^{10}$

Rerata luas area CD20 positif pada kelompok $A$ 82,72\% $(82,7176 \pm 15,782)$ dan kelompok B 46,34\% $(46,3412 \pm 13,783)$. 
Perbandingan rerata luas area CD20 positif di antara kelompok $A$ dan $B$ menunjukkan perbedaan signifikan dengan nilai $p<$ 0,001 . Secara statistik CD20 mampu membedakan karakter limfosit B pada kelompok A dan $B$. Penilaian imunoarsitektur menunjukkan ekspresi CD20 kelompok A positif difus atau tersebar merata pada membran sel dengan intensitas kuat, sedangkan ekspresi CD20 positif kelompok B terletak pada folikel di zona korteks maupun germinal center.

Pola imunoarsitektur ekspresi CD20 pada kelompok $A$ dan $B$ berbeda. Ekspresi CD20 positif difus dengan intensitas kuat pada kelompok $A$ menunjukkan proliferasi sel limfosit B monoklonal yang cenderung bersifat ganas. Hal ini sesuai dengan profil sel-sel penyusun limfoma non-Hodgkin sel B. Ekspresi CD20 positif kelompok $B$ yang terletak pada folikel di zona korteks maupun germinal center merupakan gambaran distribusi limfosit B yang sesuai pada kelenjar getah bening normal, jaringan limfoid reaktif maupun hiperplasia. 2,10

Rerata luas area CD43 positif pada kelompok A 47,67\% $(47,6588 \pm 29,508)$ dan kelompok B 45,79\% $(45,7868 \pm 18,907)$. Perbandingan rerata luas area positif antara kelompok $\mathrm{A}$ dan $\mathrm{B}$ tidak menunjukkan perbedaan signifikan dengan nilai $p=0,791$. Hasil ini menunjukkan bahwa CD43 tidak dapat digunakan sebagai antibodi tunggal untuk mengevaluasi karakter jinak atau ganas lesi limfoproliferatif secara kuantitatif. Namun demikian, pola imunoarsitektur ekspresi CD43 kelompok A dan B tampak memiliki perbedaan. Imunoarsitektur kelompok A menunjukkan ekspresi CD43 positif tersebar merata atau difus pada membran sel. Pola ekspresi CD43 pada kelompok A mirip (koekspresi) dengan CD20 pada kelompok $\mathrm{A}$. Namun, penilaian imunoarsitektur pada kelompok B menunjukkan ekspresi CD43 positif terletak di parakorteks. Pola ekspresi CD43 pada kelompok B mirip (ko-ekspresi) dengan CD3 pada kelompok B. Meskipun secara kuantitatif perbandingan luas area ekspresi CD43 positif antara kelompok $A$ dan B tidak signifikan, namun adanya ko-ekspresi $C D 43$ dan CD20 pada kelompok $A$, serta koekspresi CD43 dan CD3 pada kelompok B menunjukkan bahwa penggunaan $\mathrm{CD} 3$, CD20, dan CD43 sebagai kesatuan panel antibodi mampu membedakan karakter jinak atau ganas dari lesi limfoproli-feratif reaktif dan limfoma non-Hodgkin sel B. 18,19,20,22

Hasil penelitian yang menunjukkan luas area CD43 positif tidak berbeda signifikan secara statistik sangat mungkin disebabkan karena CD43 mendeteksi dua jenis populasi sel yang berbeda. CD43 diekspresikan oleh limfosit B neoplastik (ganas) di kelompok A, sedangkan CD43 diekspresikan oleh limfosit T dan makrofag pada kelompok B. Hal ini menjadi dasar penggunaan CD43 akan lebih akurat jika digunakan bersama-sama dengan antibodi lain yang dapat mengonfirmasi ekspresi CD43 positif. Pada penelitian menggunakan antibodi CD3 dan CD20 untuk mengonfirmasi ekspresi CD43 positif, sehingga dapat dikorelasikan dengan distribusi dan morfologi sel limfoid yang dievaluasi. 2,10,15

\section{Kesimpulan}

Ekpresi CD20 dan CD3 positif menunjukkan perbedaan bermakna antara limfoma non-Hodgkin sel $B$ dan lesi limfoproliferatif reaktif. Namun, ekspresi CD43 positif tidak menunjukkan perbedaan bermakna. Penggunaan CD3, CD20, CD43 secara simultan mampu membedakan karakteristik jinak atau ganas antara limfoma non-Hodgkin sel B dan lesi limfoproliferatif reaktif. Namun demikian, dalam menilai ekspresi CD43 positif diperlukan korelasi morfologi, distribusi sel dan imunoarsitektur dari sel-sel limfoid yang menyusun lesi limfoproliferatif. 
Saran

Dilakukan penelitian lanjutan mengenai limfoma non-Hodgkin sel B yang telah diklasifikasikan ke dalam subtipe tertentu dengan jumlah sampel yang lebih banyak.

\section{Daftar Pustaka}

1. Bégueret $H$, Vergier $B$, Parrens $M$, Lehours $P$, Laurent $F$, Vernejoux J-M, et al. Primary Lung Small B-Cell Lymphoma Versus Lymphoid Hyperplasia: Evaluation of Diagnostic Criteria in 26 Cases. The American Journal of Surgical Pathology. 2002; 26(1):76-81.

2. Boyd SD, Natkunam Y, Allen JR, Warnke RA. Selective Immunophenotyping for Diagnosis of B-Cell Neoplasms: Immunohistochemistry and Flow Cytometry Strategies and Results. Applied Immunohistochemistry \& Molecular Morphology: AIMM/Official Publication of the Society for Applied Immunohistochemistry. 2013; 21 (2):116.

3. Weiss LM, O'malley D. Benign Lymphadenopathies. Modern Pathology. 2013; 26(S1):S88.

4. Jaffe ES CE, Harris NL, Pileri SA, Stein $H$, Swerdlow SHs. Introduction and Overview of the Classification of Lymphoid Neoplasm. In: Swerdlow SH CE, Harris NL, Jaffe ES, Pileri SA, Stein $\mathrm{H}$, Thiele J, editor. WHO Classification of Tumours of Haematopoietic and Lymphoid Tissues. $4^{\text {th }}$ edition. Lyon, France: International Agency for Research on Cancer (IARC). 2017. p. 192-6.

5. Disanto MG, Ambrosio MR, Rocca BJ, Ibrahim HA, Leoncini L, Naresh KN.
Optimal Minimal Panels of Immunohistochemistry for Diagnosis of B-Cell Lymphoma for Application in Countries with Limited Resources and for Triaging Cases before Referral to Specialist Centers. American Journal of Clinical Pathology. 2016; 145(5):68795.

6. Zhang X, Aguilera N. New Immunohistochemistry for B-Cell Lymphoma and Hodgkin Lymphoma. Archives of Pathology \& Laboratory Medicine. 2014;v138(12):1666-72.

7. Castellarin P, Pozzato G, Tirelli G, Di Lenarda R, Biasotto M. Oral Lesions and Lymphoproliferative Disorders. Journal of Oncology. 2010; 2010: 202305.

8. Kim H-J, Ko YH, Kim JE, Lee S-S, Lee $H$, Park $G$, et al. Epstein-Barr VirusAssociated Lymphoproliferative Disorders: Review and Update on 2016 WHO Classification. Journal of Pathology and Translational Medicine. 2017; 51(4):352.

9. Dong HY, Gorczyca W, Liu Z, Tsang P, Wu CD, Cohen P, et al. B-Cell Lymphomas with Coexpression of CD5 and CD10. American Journal of Clinical Pathology. 2003;119(2):218-30.

10. Higgins RA, Blankenship JE, Kinney MC. Application of Immunohistochemistry in the Diagnosis of Non-Hodgkin and Hodgkin Lymphoma. Archives of Pathology \& Laboratory Medicine. 2008; 132(3):441-61.

11. Garcia CF, Swerdlow SH. Best Practices in Contemporary Diagnostic Immunohistochemistry: Panel Approach to Hematolymphoid Proliferations. Archives of Pathology \& Laboratory Medicine. 2009; 133(5):756-65. 
12. Wang H-Y, Zu Y. Diagnostic Algorithm of Common Mature B-Cell Lymphomas by Immunohistochemistry. Archives of Pathology \& Laboratory Medicine. 2017; 141 (9):1236-46.

13. Das DK. Contribution of Immunocytochemistry to the Diagnosis of Usual and Unusual Lymphoma Cases. Journal of Cytology. 2018; 35(3):163.

14. De Tute R. A Review of Flow Cytometry and its Use in the Diagnosis and Management of Mature Lymphoid Malignancies. 2011; 58(1):2-12.

15. Horvat M, Kloboves Prevodnik V, Lavrencak J, Jezersek Novakovic B. Predictive Significance of the Cut-Off Value of CD20 Expression in Patients with B-Cell Lymphoma. Oncology reports. 2010; 24 (4):1101-7.

16. Kennedy GA, Cull G, Gill D, Marlton P, Norris $D$, Cobcraft $R$. Identification of Tumours with the CD43 Only Phenotype During the Investigation of Suspected Lymphoma: a Heterogeneous Group not Necessarily of T Cell Origin. Pathology. 2002; 34(1):46-50.

17. Mitrovic Z, lqbal J, Fu K, Smith LM, Bast $M$, Greiner TC, et al. CD 43 Expression is Associated with Inferior Survival in the Non-Germinal Centre B-Cell Subgroup of Diffuse Large B-Cell Lymphoma. British
Journal of Haematology. 2013; 162(1):8792.

18. Bacon CM, Du M-Q, Dogan A. MucosaAssociated Lymphoid Tissue (MALT) Lymphoma: a Practical Guide for Pathologists. Journal of Clinical Pathology. 2007; 60(4):361-72.

19. Lai R, Weiss LM, Chang KL, Arber DA. Frequency of CD43 Expression in NonHodgkin Lymphoma: a Survey of 742 Cases and Further Characterization of Rare CD43+ Follicular Lymphomas. American Journal of Clinical Pathology. 1999; 111(4):488-94.

20. Lee P-S, Beneck D, Weisberger J, Gorczyca W. Coexpression of CD43 by Benign $B$ Cells in the Terminal lleum. Applied Immunohistochemistry \& Molecular Morphology. Appl Immunohistochem Mol Morphol. 2005; 13(2):138-41.

21. Rawal A, Finn WG, Schnitzer B, Valdez R. Site-Specific Morphologic Differences in Extranodal Marginal Zone B-cell Lymphomas. Archives of Pathology \& Laboratory Medicine. 2007; 131(11):1673-8.

22. Ma Xb, Zhong Yp, Zheng $Y$, Jiang J, Wang Yp. Coexpression of CD 5 and CD 43 Predicts Worse Prognosis in Diffuse Large B-Cell Lymphoma. Cancer Medicine. 2018; 7(9):4284-95. 